\title{
EUROPEAN UNION LAW'S PROXIMITY TO CITIZENS THROUGH EDUCATION AND THE USE OF DIGITAL TECHNOLOGIES
}

\author{
Maria Manuela Magalhães Silva', Dora Resende Alves² \\ ${ }^{1} \mathrm{PhD}$ in Law. Associate Professor at Universidde Portucalense (UPT) and Member \\ integrated and principal investigator of Instituto Jurídico Portucalense (IJP) (PORTUGAL) \\ ${ }^{2} P h D$ in Law. Auxiliary Professor at Law Department at Universidade Portucalense (UPT) \\ and Permanent researcher at the Instituto Jurídico Portucalense (IJP) (PORTUGAL)
}

\begin{abstract}
Education forms the basis for active citizenship. The integration model followed in the construction of the European Union (EU) includes the action of its institutions, which develop competencies and lines of implementation through legislative, decision-making and sanctionary paths. All procedures involved result in the preparation of documents. The use of technology has extended access, giving these digital media a legal category as a source of law; today available on the e-mail address or in the EU's own publications; of access to interested specialists or to the general public, being in the interest of citizens, academics or institutions. Differentiated levels of access are created, which is not unrelated to the degree of digital literacy. The European Union is a union of common values and is based on the values of democracy, defense of human rights and the rule of law and, as such, with a strong component of creation and respect for legal standards. Concerns about the transparency of procedures and accessibility are real, but not always completely effective.
\end{abstract}

Education is one of the keys to the future and can and must be part of the solution to solving problems such as, in this case, accessibility to information on European Union law.

The chosen theme concerns the effective application of EU rules as an important aspect for European citizens that affects their daily lives and how citizens feel the closeness to EU law. As the problem is not always the absence of EU legislation, but rather the fact that such legislation can be known and applied effectively. The implementation of EU law is a challenge that requires a greater emphasis on enforcement to serve the general interest. And what role does education and the use of digital technologies play in this context? How can investment in education considering new technologies bring citizens closer to the functioning of the EU? Will this lead to a strengthening of democracy?

The aim of this analysis is to demonstrate that, as the Member States are primarily responsible for the application of EU law, there is still a way to achieve more efficiency in the application of European legislation, which implies, on the part of States, public policies aimed at education and training on new technologies that may be an instrument to motivate and increase knowledge of said legislation, which in turn will allow a more effective exercise of active citizenship.

Considering the embryonic nature of this study, a methodology was designed that focuses on the use of European Union law sources, through systematic and methodologically selected normative interpretation. It focuses on specialized publications and above all official documents (legislative or preparatory) that enshrine the issue. The theoretical-academic focus is consolidated through systematic normative interpretation and aims to expand knowledge, in a qualitative and exploratory approach. Without presenting quantitative data, the purpose is to bring to discussion and debate the role, value, education capacity and ability of using new technologies for the dissemination and application of European Community law.

Keywords: education; technologies; legislation; application procedures; European Union law.

\section{INTRODUCTION}

A united Europe is not a concept taken for granted and it remains an option. An option that allowed a near 70 year old peace to be liven in Europe apart from other achievements such as Member-State enlargement, a single market and a single currency or even European citizenship [1]. And if it was before 1950 that the idea of replacing the use of armed force by the force of law arose, the idea of making a "soft power" prevail in conflict resolution remains current and urgent today in which we cannot allow force to override the law where value of the Rule of Law arises. In this context (if not in any context), education forms the basis for an active citizenship [2].In this case, the integration model 
followed in the construction of the European Union (EU) comprises the action of its institutions, in order to develop competences and lines of implementation through legislative, decision-making and sanctioning paths.

And all the procedures involved result in the preparation of documents. Reading documents accessible through publication in the official journal or in the press. The use of technology has extended access by conferring on these digital media a legal category of legal source of law available at the EU's own email address or publications, a few only for access by interested experts or many to the general public and are in the interests of citizens, academics or organizations. Differentiated levels of access are created, which is not unrelated to the degree of digital literacy, when $44 \%$ of the EU population is recognized as low digital skills [3, pp. 1-12]. Since digital competences nowadays interfere with the capacity for democratic participation [4, pp. 23-28]. The European Union is a union of common values and is based on the values of democracy, the defense of human rights and the rule of law and, as such, with a strong component of creation and respect for legal norms. Concerns about transparency of procedures and accessibility are real, but not always fully effective.

Education is one of the keys to the future [2, p. 1] and can and must be part of the solution to solve problems such as information accessibility on EU law.

The present state of uncertainty about the future of the European Union[5, p. 13] justifies a re-reading of EU law and its application, as is apparent from recent documents released by its institutions. The theme chosen is the effective application of EU rules as an important aspect for European citizens that affects their daily lives and how citizens feel proximity to EU law. The problem is not always the absence of EU legislation, but rather the fact that such legislation is known and implemented effectively. The implementation and enforcement of EU law is a challenge that requires greater emphasis on enforcement in order to serve the general interest. And what role does the education and use of digital technologies play in this context? How can investment in education considering new technologies bring citizens closer to the functioning of the EU? Will you lead this path to a strengthening of "democraticity"?

The aim of this analysis is to demonstrate that with Member-States being the main responsible for implementing EU legislation, there is still a path to be taken to achieve more effectiveness in the implementation of European legislation, which implies on the part of States public policies aimed at education and training on new technologies that could be an instrument to motivate and increase knowledge of such legislation, which in turn will allow for a more effective exercise of active citizenship. Education on the European Union is not yet sufficient and there are times of crisis that demonstrate this and which could have been avoided with greater transparency of political processes and with greater emphasis on the education of European citizens, see the non-ratification of the 2004 Constitutional Treaty or the referendum process that led to the so-called "Brexit" in 2020.

Considering the embryonic nature of this study, a methodology was designed that focuses on the use of EU law sources through systematic and methodologically selected normative interpretation. It focuses on specialized publications and above all official documents (legislative or preparatory) that enshrine the issue. The theoretical-academic approach is consolidated through systematic normative interpretation and aims to expand knowledge in a qualitative and exploratory approach. Without presenting quantitative data, the purpose is to bring to the discussion and debate the role, value and capacity of education and the use of new technologies for the dissemination and application of Community European law. In this sense, the use and citation of electronic addresses that illustrate this new facet of digital access in this matter, as in so many others, is used, and that reflects the need for the right knowledge for its best use.

\section{EUROPEAN UNION AND LAW}

As the Commission states: "The European Union is based on law, pursues many of its policies through legislative instruments and is based on respect for the rule of law." [6, p. 2].

The rule of law [7, pp. 695-710], [8] is therefore a value of the European Union and one of the mottos of European construction, then and now, present in the Schuman Declaration of 1950 [9] or in documents tracing the current action vectors [10]. Today, in the Treaty on European Union (TUE), article 2 and safeguarded through the Article 7 mechanism [11, p. 3], much earlier, even in 1986, the case-law of the Court of Justice had stressed that the European Union is a "community of law" [12, Para. 23]. The idea of the rule of law is a source for the general principles of the law of judicial protection arising from that which exist in the legal order of the Union; it is not always expressed, it is 
an inspiring principle and results as a common denominator which is also present in the constitutional traditions common to the Member States [13, pp. 1-3], [14] .

The value and principle of the European Union, this ideal present since the genesis of the original European construction remains the center of concerns because it faces indentations and setbacks from what has already been achieved in this nearly 70-year journey, even putting the possibility of a new revision to the treaties to strengthen the protection of the rule of law as the "backbone of European liberal democracy and one of the founding principles of the EU arising from the constitutional traditions of the Member States" [15, pp. 2-3].

The rule of law is only materialized when the entire organization of political power and constitutional organization contribute to guaranteeing and promoting the fundamental rights of the human person $[16$, p. 246] according to the idea formulated in international documents as are the preamble to the Universal Declaration of Human Rights of 1948: "the protection of human rights through a regime of law is essential" [17, p. 11], of the Statute of the Council of Europe of 1949: "adhering to spiritual and moral values, which are the common heritage of their peoples and which are at the origin of the principles (...) the rule of law" [17, p. 275] and the preamble to the 1950 European Convention on Human Rights: "a common heritage (...) respect (...) for the rule of law" [17, p. 78]. In both cases, without the coincident expression in translations into the various languages and without the definition of the concept [18, Para. 17]. There will be a path of education for citizenship, which involves a literacy campaign of the Law, in order to explain to ordinary citizens the role of the law in their daily lives organized in political societies governed by law [19]. The reinforcement lies in the idea that "education is the basis for active citizenship" [2].

With a concept not entirely coincidental in the internal legal order of each Member State (the English rule of law or "l'état de droit" in France or the German "Rechtsstaatsprinzip" [18, Para. 4] and already characterized in the case-law of the Court of Justice [15, p. 16], the defense of the rule of law [20, p. 238 ] is present in Europe as a democratic principle and challenge to keep it effective [21, p. 6].

It is in the concerns of the Economic and Social Committee [22, p. 11] that the membership of a new European country to the EU implies that it ensures the permanence of the rule of law, following the socalled membership criteria or "Copenhagen criteria". However, there is no procedure other than article 7 , which stipulates a form of control over respect for the rule of law after the membership of a Member State. The proper functioning of the EU stems from mutual trust between the European institutions and the Member States and the EU believes that member states' internal measures respect the same principle of the rule of law, but that balance may fail even though the Article 7 TEU mechanism has never actually been triggered. This preventive and sanctioning resource - which leads to the verification of the existence of a "risk of serious breach" of the figures referred to in Article 2 of the TEU or the verification of its "serious and persistent breach" - has an undesired political impact, and is therefore seeking another prior and complementary step, as presented by the Commission [23], [24, p. $10 ; 1]$ and remains in its most recent concerns [25, p. 38], welcomed by the European Parliament [15, p. 14].

It is certain that there is always the use of action for failure to fulfil obligations in accordance with Articles 258 to 260 TFEU. It is an EU-specific instrument as an integration organization, which can be used when EU law is not applied by a Member State. However, the idea arises of creating a prior means in the face of only the threat before the serious infringement or the already infringement in the application of EU law is consummated, as a means of intervening to protect the rule of law as a common value of the Union although in the mere form of systemic threat. A mechanism that proves effective to regularly assess Member States' compliance with EU core values, creating a basis for an early warning instrument [26, p. 38].

The issue remains of the greatest relevance on the political agenda and even the European Parliament has called on the European Commission to submit a proposal on the drafting of a Union pact for democracy, the rule of law and fundamental rights [22] , a matter which has already been the attention of the European Economic and Social Committee [15, p. 15] and the proposal for discussions by the Council [13]. In any event, this is nothing more than the strengthening and continuit6 of the rule of law framework as already outlined by the Commission in its 2014 document.

Both the EU and the Member States should continue to promote in all actions, partnerships or instruments, the value of the rule of law [27, p. 18, § 50]. However, much will be the policy of education and training that the common values and general principles of law will be upheld [28, p. 3]. The education system, from early childhood to higher education, is responsible for maintaining the 
skills (knowledge, skills and attitudes) essential to the exercise of democratic ideals, contributing to the creation of the awareness of a European citizenship.

\section{EUROPEAN UNION LAW}

The European Union is based on the common values of democracy, the defense of human rights and the rule of law and [13] as such, with a strong component of creation and respect for legal norms.

The European Union is neither a federation of States nor a mere organization of cooperation between governments. It has a unique character. EU countries have pooled their sovereignty in some areas, which means, in practice, that Member States delegate some of their powers to the common institutions they have set up to ensure that matters of common interest can be decided democratically at European level.

Community institutions present themselves as an example of positive integration. The Treaties have established the competences, rules and procedures that the EU institutions must follow.

In the four-party institutional system foreseen by the original Treaties the intention to avoid the concentration of powers by their "founding fathers" emerged, and this became a reference for the developers of the European construction process. The original Communities had a more complete institutional structure than the classical international organizations, which in general terms have been maintained to this day.

The institutions of the European Union find the general principles on their functioning set out in the Treaties: Treaty on European Union (TEU) and the Treaty on the Functioning of the European Union (TFEU). It is the original law itself which states what determinations will arise through secondary law published in the Official Journal of the European Union. This is the case of EU law, in a collection already of great extension today: regulations, directives and decisions [29, p. 2, § 4-6], recommendations and opinions. However, there are also numerous acts adopted by the Community institutions, some foreseen by articles of the Treaties and others, even though not expressly provided for by the Treaties (atypical because not provided for in Article 288 TFEU) previously born of Community practice [30, pp. 81-104]. As a rule, these are non-binding legal instruments [31, pp. 110$112 ;$ p. $111-\S E]$, the so-called soft law, although sometimes they may be mandatory for some services or in some contexts [32].

However, "[the] legislation only fully fulfills its objective if it is properly applied" [6, p. 2] and this presupposes an educational path that allows it, that is, an education of the citizen to access the available information and understand it. How often the legal aspects are so intricate that only specialists have access to them - this is true right from the start in the form of institutional treaties. Only through education is possible to understand the documents that are the Treaties of the European Union and the Treaty on the Functioning of the European Union, in the versions introduced by the Lisbon Treaty of 2007.

For citizens and businesses to enjoy the benefits of EU law, it is essential that Member States comply with the legislation. It is valid for national legislation, of course, but here we underline European Union law in particular that they transpose the European Directives into their national legal order within the agreed time limits as is apparent from a whole Union program to achieve better legislation[33], i.e. to make the law applicable and to monitor the outcome [34].

\section{DECISION-MAKING PROCESS IN EUROPEAN UNION LAW}

The EU's institutional architecture is not easy to understand at first reading [35, p. 5]. There is not only one way of legislative procedure under EU law and the documents that are part of this acquis are endowed with varied legal force. In general, the right of legislative initiative rests with the Commission [36] and the decision-making process with the Council together with the European Parliament. It is the "Union method" whereby essentially the European Council defines the guidelines and priorities of general policies, the Commission promotes the general interest of the Union and takes appropriate initiatives, the European Parliament and the Council jointly exercise the legislative function and budgetary function on the basis of the Commission's proposals. The Court of Justice of the European Union represents the defense of law in the Community legal order, ensuring its uniform interpretation. Organized in a system of checks and balances that has evolved over the various revisions to the treaties, with expression in the latter by the Lisbon Treaty [37]. 
The decision-making process takes place mainly between the institutions - Commission, Council and European Parliament - with the rules and exceptions of any decision-making procedure, however, with a legitimacy put into doubt in the media, taking into mind the two levels between which it takes place: the European and the Member States [35, p. 5], the so-called democratic deficit, which has been widely criticized alongside the analysis of the quality of democracy in the EU[38, p. 49] so much is a sensitive point that the EU itself tries to justify and improve the transparency of decision-making through documents indicating it.

The European legislative process is of an essential characteristic that it is a negotiating process which calls for the participation of the European institutions, the Member States and even the citizens [39, p. 7]. The Council and the European Parliament share legislative power in a balance of power between the peoples and states of Europe in the public interest of the European Union [40, p. 201].

The rule is the ordinary legislative process, although there are still procedural specificities in several matters. It is the Treaty itself that says what the ordinary legislative procedure is and when it is a special legislative procedure (Article 289, paragraphs 1 and 2, TFEU) and when it is a special legislative procedure, case by case.

Although the decision-making process is also ensured by a so-called "comitology"[41, pp. 13-18] that seeks greater accountability in the decision-making process which can happen through proposals to amend the regulated procedures that are in progress[42, p. 5]. Comitology committees differ from other existing entities such as expert groups providing knowledge to the Commission while those serve to assist it in exercising the implementing powers conferred on it by basic legislative acts[43]. In a procedure adopted since 2011 as it prepares to adopt an implementing act, the European Commission must consult a committee composed of representatives from each of the Countries of the European Union (EU) on the project it proposes[44] in this concern of transparency and greater proximity. Again, there is a growing concern of the European Union with the idea of better lawmaking "when standards are well directed, concrete and written in a simple way, it is much easier to correctly apply them and to achieve the objectives advocated, whether economic, social or environmental [45].

\section{PUBLICIZING EUROPEAN UNION LAW}

However, as has been said, legislative procedures are not easy for ordinary citizens to follow which in itself would justify greater investment by Member States in education about the European Union. The possibility of accessing the knowledge of the law, national or of the European Union is crucial, in order to guarantee the easiest and possible access nowadays both to the European legislation and to the legislation of the Member States that gives application to European instruments[29, p. 2, § 1]. As the European Parliament recalls: "in a European Union based on the rule of law and the certainty and predictability of legislation, European citizens must, in their own right, be the first to be informed in a clear, accessible, transparent and timely manner"[46, p. 247, § 3] in than all legislation.

Just as a curious note for Portugal as a Member State, it should be pointed out that the problem of the dissemination of the norms is almost as old as the general laws of the Kingdom of Portugal, which will have arisen by 1211 , with the difficulties of disclosure at the time. At the time of the emergence of the first major compilation of Portuguese laws, the Afonsine Ordinances [47, p. 129], the question of their validity resulted from the lack of means of dissemination, making the work of 1446 only in its reformulation of 1521, already under the designation of Manueline Ordinances, be applied throughout the Kingdom of Portugal, because it could already be had the press in the kingdom since 1508.

In some ways, the issue remains current, as new technologies have new forms of access to legislative documents. In the European Union since $1^{\text {st }}$ of July 2013, only the electronic edition of the Official Journal is authentic and has legal effects[48, pp. 1-3], [49] and "the adoption of this Regulation has been an essential step towards ensuring easy and direct access to EU law and providing legal certainty for citizens, businesses and institutions"[29, p. 3, § 13]. The same has been the case at national level since 2016. However, the level of digital literacy of citizens does not always keep pace with technological progress and political power is urgently concerned about this gap.

The publication takes place in the 1960s[39, p. 19] and it is in 1969 that the Office for Official Publications of the European Communities, publisher of the institutions, agencies and other bodies of the European Union, officially established itself as an independent body in Luxembourg[50, p. 18], [51, p. 19], [52, pp. 12-15], [53, pp. 15-16]. Although the Service did not officially become an independent body until 1969, its origins date back to the service of publications of the European Coal and Steel Community, which published the Official Journal of the European Coal and Steel Community from 
1952, published the first issue in four languages (German, French, Italian and Dutch) on 30 December 1952[54]. The Internet has had a considerable impact on the increased dissemination of Community information largely fuelled and managed by the Publications Office on the integrated EUR-Lex/CELEX legislation portal, operating platforms that make all European law available directly and free of charge[29, p. 3], [39, p. 20, § 7].

With the entry into force of the first enlargement of the Communities on 1 January 1973, the Official Journal of the European Communities it was published in 6 languages (until then it was in 4). On 1 January 1986, with the entry into force of the third enlargement of the Communities it was published in 9 languages (until then it was 7). Later, with the entry into force of the fourth enlargement of the Communities on 1 January 1995, it would move to 11 languages (until then it was 9). On 1 February 2003, with the entry into force of the Treaty of Nice[55], the designation of the Official Journal of the European Communities as the Official Journal of the European Union[56] as a result of the amendment of the current Article 297 TFEU then by the Treaty of Nice[57].

Official newspapers are thus available in the official languages of the Member States from the date of their entry. The legislation in force on the date of the entry is translated and published in special editions. The principle of publicizing EU acts is intended to serve the principles of legality, equality and prohibition of agency, transparency and legal certainty and the protection of the trust of EU citizens and residents.

However, once the issue of accessibility is resolved, does not mean that European citizens know about EU law. In this context, this problem remains a focused and maintaining aspect in the action programs outlined: improving people's lives through access to justice and their daily knowledge of their rights[58, p. 4]. It is true that many of the European programs are aimed at legal practitioners, including judicial and administrative authorities, in the sense of training, the concern always extends to the general public focusing on the knowledge of the principles inherent in the treaty [58, p. 11].

\section{ENFORCEMENT OF EUROPEAN UNION LAW}

Again, in the Commission's words: "The success of achieving its many objectives, as set out in the Treaties and legislation, depends on the effective application of Community law in the Member States" [6, p. 2].

Effective enforcement will result in improved safeguarding of the rights of citizens, who are increasingly aware of their rights. As is apparent from a survey on Citizenship of the Union, the vast majority of Europeans (91\%) is well informed about the rights of citizenship of the European Union[59].

Member States are responsible for the application of EU law, its correct application and implementation[46, p. 249, §20], [60, p. 148, §10]. First of all, it is their responsibility for the application of EU law, both with regard to the Treaties and to secondary law[61, p. 5]. Clearly, this is the case in the rules that have a direct effect in a deferred manner in the transposition of directives and when expressly indicated in the long-term policies or guidelines[27, p. 23, § 68]. But other actors are responsible for the correct and timely implementation of EU law, such as, of course, the European institutions themselves and then regional and local authorities and courts[6, p. 3]. It is necessary to underline the transposition of directives where much of the non-compliance by Member States can jeopardize the enforcement of the rights of European citizens and there is union attention devoted to this point [34].

National courts are "the "common courts" to ensure compliance with legislation and contribute effectively to its implementation in specific cases"[24, p. 11,§ 2]. National courts are then functional courts implementing EU law and the "proper application of Community law depends on national authorities taking the right decisions"[23, p. 6] for which the mechanism of Article 267 TFEU exists. But the correct application of EU law also involves training legal enforcement professionals, not only, but specifically judges[24, p. 13], [62], [63], so the focus on education is always to be highlighted and is present in the EU's concerns. Initial, complementary or alternate training measures[23, p. 7], [61, p. 6] are examples of actions to support this performance that are promoted by the EU to monitor Member States as a whole in their efforts to implement European legislation[24, p. 11] .

Otherwise, and to reach the same point, all citizens have the possibility to use national courts as the first judges of Community law[61, p. 18, c)] in all situations where vertical direct effect of EU law is produced[64, Para. 39]. This path is currently expanding as is currently the case during the deadline for transposition a Directive on the private application of the defense of competition with civil liability 
actions with a predominantly compensatory function in which compensation is sought, compensation for repairing the damage caused[65, pp. 1-19] Only in 2018 it was transposed in Portugal by Law No. $23 / 2018$ of June 5 . Any citizen or undertaking suffering damage as a result of non-compliance with Community antitrust rules (Articles 101 and 102 TFEU) shall be able to claim redress from the person who caused the damage, as long ago recognized by the case-law[66]. The right of victims to claim compensation is now guaranteed by EU law by secondary law[67].

Within the institutions, the Commission stands out in this respect because it is present in various related functions (Article 17 TEU): it is responsible for the proposal for new acts of law and for the proposals to amend existing ones; it works closely with the Member States in implementing measures and it is responsible for the capacity of guardian of the Treaties which has the authority and responsibility to ensure compliance with Union law $[6, p .3]$. It "has a duty to monitor member states' action in the implementation of EU law and to ensure that national legislation and practices are in line with it, under the control of the Court of Justice of the European Union." [46, pp. 14; 3]. As already been mentioned, recourse to Article 258 TFEU depends on the Commission's discretionary assessment in deciding whether, and when, to initiate infringement proceedings and to refer the matter to the Court. Very numerous cases are raised, demonstrating that the guardian is attentive, although not all of them even demand the intervention of the Court of Justice under Article 260 TFEU for the sincere cooperation on the part of the Member States is to be achieved. Furthermore, the CJEU itself "recognizes to individuals an active role in the legal construction of the European Union that goes beyond the mechanisms of participation (by representative means) in the decision-making procedures provided for in the Treaties" because they have "an opportunity to exercise that democratic vigilance and ensure respect for the rights that the Union legal order recognizes to them[68] .

Again, in a latter strand, citizens can "contribute significantly to the control carried out by the Commission by reporting non-compliance with EU law by Member States"[24, p. 10]. Complaints made by citizens deserve all the care of treatment[46, p. 250, § 30], [69], but it must not be forgotten that the Commission does not have the resources to respond with an investigation to all of them and, on several occasions, the Commission has stated the need to adapt the means it has to investigate the most serious offences. There have been developments in this area on the handling of complaints as an important means of detecting infringements of EU law, as announced by Commissioner Margrethe Vestager at the time responsible for competition policy[24, p. 16, § 4], while still with an example in this policy with the launch of a new instrument to make it easier for citizens to anonymously alert the Commission to secret cartels and other anti-trust rule offences[70].

The issue concerns the effective application of EU rules as an important strand for Europeans that inaudibly affects their daily lives[29, p. 2]. The problem is not always the absence of EU legislation but rather the fact that this legislation is not always applied effectively. The implementation and enforcement of EU law is a challenge that requires greater emphasis on enforcement in order to serve the general interest. To this end, citizens should have access to all necessary information[60, p. 147, § 3]. The Union is based on mutual trust between EU Member States and their legal systems under the Treaty of Lisbon[13, p. 2] as it is underlined that Member States are the main responsible for the implementation of EU law[44]. And the task of identifying what is the case with the application of EU law is not always easy, most in the field of fundamental rights [71, p. 180].

For its part, the Union is currently seeking more transparency and accountability in the implementation procedures and is concerned with giving citizens back knowledge of the correct application of a very significant legislative acquis. It is necessary to meet the legitimate expectations of citizens about the advantages brought by the EU and its right. This translates into concrete measures to increase the exchange of information and the appropriate and swift treatment of the questions and complaints submitted, as a means of achieving objectives and making the freedoms guaranteed by the Treaties certain[6, p. 2].

Another mechanism that the Union makes use of is public consultations[72]. Not being new, it gains a new dimension as an increase in the digital dimension of citizenship, in an increasingly digital world. And it is a route adopted by the European Commission 2019/2024[73] for connection with the citizen. Once again it is stressed that only by education can this fruitful access be made. 


\section{CONCLUSION}

Democratic values and the rule of law remain essential, from the first draft of a union in Europe to the European Union today. Its dissemination is not yet enough. The proper application of EU law is essential to maintain and defend these values, for the very success of the EU and this involves the contribution of every informed and attentive citizen. And the protection of the rule of law is not a given, it is something that needs permanent construction and civic participation.

Education, from early childhood to university studies, should guide learners to the highest quality civic training to ensure a path of freedom and promotion of a culture of global peace. In a building of citizenship. And today, in digital access it has become a new area of literacy that still raises concerns.

The union of Europe was made by people and by the people who live in it and with it they have ties. European citizenship resulted from a construction of more than 70 years. It is in the confidence of the citizens of the Union that the rule of law must be founded, a confidence which, in order to be achieved and maintained, requires the correct application of EU law, created by its institutions and on the basis of the original law of the Treaties.

Not so long ago in 2017, the European Union celebrated the 60th anniversary of the signing of the Treaty of Rome. This anniversary provided an opportunity to celebrate the EU's achievements, but also to address Europe's main political, economic and social challenges[74, p. 11, 2.1]. Citizens' confidence in the European Union has declined in many Member States. Then, for the first time in its history, the Union saw the departure of a Member State, the United Kingdom, through what became known as "Brexit". It turns out that, even after the process initiated, it is not yet entirely clear to the average European citizen, not even to be enlightened, to monitor that process and, as well, how to know European Union law. There is still a way forward.

\section{REFERENCES}

[1] J. C. Juncker, “L'Europe aujourd'hui et demain," SPEECH/17/341. 2017.

[2] European Commission, "Communication from the Commission to the European Parliament, the Council, the European Economic and Social Committee and the Committee of the Regions Document COM(2017) 673 final - 14.11.2017." European Union, Brussels, 2017.

[3] Council of the European Union, "Council conclusions on shaping Europe's digital future. 2020/C 202 I/01 ST/8711/2020/INIT JOUE CI 202/I - 16.06.2020." Official Journal of the European Union, Brussels, 2020.

[4] Council of the European Union, "Council conclusions on media literacy in an ever-changing world. 2020/C 193/06 ST/8274/2020/INIT. JOUE C 193/23 - 9.06.2020." Official Journal of the European Union, Bruxelas, 2020.

[5] E. da Conceição, O futuro da União Europeia. Fundação Francisco Manuel dos Santos, 2016.

[6] European Commission, "Comunicação from the Commission- A Europe of Results - Applying Community Law. COM(2007) 502 final - 05.09.2007." European Union, 2007.

[7] European Commission, "European governance - A white paper. Document COM/2001/0428 final 12.10.2001." Official Journal of the European Communities, Brussels, 2001.

[8] D. R. Alves and C. Trindade, "Do artigo $7^{\circ}$ do Tratado da União Europeia na situação da Polónia," in Estudios de Derecho Iberoamericano. Vol. III, Universidade Lusófona do Porto, 2010, pp. 695710.

[9] European Union, "The Schuman Declaration - 9 May 1950," Europe Day. [Online]. Available: https://europa.eu/european-union/about-eu/symbols/europe-day/schuman-declaration_en

[10] European Commission, "Communication from the Commission to the European Parliament, the Council, the European Economic and Social Committee and the Committee of the Regions Supporting the preventionof radicalization leading to violent extremism. Document $\operatorname{COM}(2016)$ 379 final." European Union, 2016.

[11] European Commission, "Comunicação da Comissão ao Conselho e ao Parlamento Europeu sobre o artigo $7^{\circ}$ do Tratado da União Europeia - Respeito e promoção dos valores em que a União assenta. Documento COM/2003/0606 final de 15.10.2003." European Union, 2003. 
[12] Court of Justice of the European Union, "Judgement of 23 April 1986, Les Verts, C-294/83, ECLI:EU:C:1986:166." Court of Justice of the European Union, 1986.

[13] European Commission, "Comunication from the Comission to the European Parliamento and the Council - A new EU Framework to strengthen the Rule of Law. Document COM(2014) 158 final 11.03.2014." European Comission, Brussels, 2014.

[14] European Commission, "Speech: The EU and the Rule of Law - What next?" European Comission, Brussels.

[15] European Parliament, "European Parliament resolution of 8 September 2015 on the situation of fundamental rights in the European Union (2013-2014) (2014/2254(INI) (2017/C 316/01). JOUE C 316/2 - 22.09.2017." União Europeia, Bruxelas, 2017.

[16] J. Miranda, Direitos Fundamentais. Almedina, 2017.

[17] J. B. Gouveia, Textos Fundamentais de Direito Internacional Público. Almedina, 2014.

[18] Council of Europe, "Report on the rule of law - Adopted by the Venice Commission at its 86th plenary session (Venice, 25-26 March 2011) - CDL-AD(2011)003rev-e." Council of Europe, Strasbourg, 2009.

[19] S. P. Fernandes, "First steps in a literacy campaign for a European political community - what is the EU based on the Rule of Law?," Blog UNIO, 2019. [Online]. Available: https:/officialblogofunio.com/2019/04/01/editorial-of-april-2019/

[20] M. M. M. Silva and D. R. Alves, Noções de Direito Constitucional e Ciência Política. Lisboa: Rei dos Livros, 2016.

[21] European Commission, "Comunicação da Comissão ao Parlamento Europeu, ao Conselho, ao Comité Económico e Social Europeu e ao Comité das Regiões - Estratégia de alargamento da UE. Documento COM(2015) 611 final - 10.11.2015." European Union, Brussels, 2015.

[22] European Economic and Social Committee, "Opinion of the European Economic and Social Committee on The European control mechanism on the rule of law and fundamental rights (owninitiative opinion). C 34/8 - 2017/C 034/02 - 2.2.2017." Official Journal of the European Union, Brussels, 2017.

[23] European Commission, "Communication from the Commission to the Council and the European Parliament on Article 7 of the Treaty on European Union - Respect for and promotion of the values on which the Union is based. Document COM/2003/0606 final - 15/10/2003." European Union, Brussels, 2003.

[24] European Commission, "Communication from the Commission - EU law: Better results through better application." Official Journal of the European Union, Brussels, 2017.

[25] European Commission, "Communication from the Commission to the European Parliament, the Council, the European Economic and Social Committee and the Committee of the Regions - 2016 Report on the Application of the EU Charter of Fundamental Rights. Document COM(2017) 239 final -." European Union, Brussels, 2017.

[26] European Parliament, "European Parliament resolution of 12 March 2014 on evaluation of justice in relation to criminal justice and the rule of law (2014/2006(INI))." Official Journal of the European Union, Brussels, 2017.

[27] European Commission, "Communication from the Commission to the European Parliament, the Council, the European Economic and Social Committee and the Committee of the Regions. Document COM(2016) 740 final - 22.11.2013." European Union, Brussels, 2016.

[28] Council of the European Union, "Conclusions of the Council and of the Representatives of the Governments of the Member States, meeting within the Council, on Inclusion in Diversity to achieve a High Quality Education For All." Official Journal of the European Union, Brussels, 2017.

[29] European Union, "Report on access to law." Official Journal of the European Union, Brussels, 2015.

[30] D. Dero-Bugny, "Le livre vert' de la Commission européenne," Rev. Trimest. droit Eur., vol. 41, no. 1, 2005. 
[31] European Parliament, "European Parliament resolution of 12 September 2013 on the application of the principle of equal pay for male and female workers for equal work or work of equal value (2013/2678(RSP))." Official Journal of the European Union, Brussels, 2016.

[32] D. R. Alves, "O direito do consumidor através da aplicação do direito da União Europeia," in Atas do I Congresso Internacional de Direito do Consumidor - Os desafios do mercado digital para os contratos de consumo, 2020.

[33] European Commission, "Better regulation: why and how." [Online]. Available: https://ec.europa.eu/info/law/law-making-process/planning-and-proposing-law/better-regulationwhy-and-how_en

[34] European Commission, "2019 Commission report and factsheets on monitoring the application of EU law," Annual reports on monitoring the application of EU law, 2020. [Online]. Available: https://ec.europa.eu/info/publications/2019-commission-report-and-factsheets-monitoringapplication-eu-law_en

[35] European Commission, White Paper on the Future of Europe - Reflections and scenarios for the EU 27 by 2025. Document COM(2017) 2025 final - 01.03.2017. Bruxelas: European Union, 2017.

[36] European Commission, "How decisions are made." [Online]. Available:

https://ec.europa.eu/info/strategy/decision-making-process/how-decisions-are-made_en

[37] S. O. Pais, "O Tratado de Lisboa e a renovação das instituições da União Europeia," in Cadernos O Direito - O Tratado de Lisboa, vol. 5, Almedina, 2015, pp. 319-350.

[38] C. Moury, A democracia na Europa. Fundação Francisco Manuel dos Santos, 2016.

[39] R. M. Marrana, "O acesso à informação no quadro do funcionamento da União Europeia," Rev. Ciências Empres. e Jurídicas. Inst. Super. Contab. e Adm. do Porto, vol. 21, pp. 7-42, 2012.

[40] M. P. Roque, "A separação de poderes no Tratado de Lisboa - avanços e recuos na autonomização da função administrativa europeia," in Cadernos O Direito - O Tratado de Lisboa, Almedina, 2010, pp. 191-243.

[41] European Parliament and Council of the European Union, "Regulation (EU) No 182/2011 of the European Parliament and of the Council of 16 February 2011 laying down the rules and general principles concerning mechanisms for control by Member States of the Commission's exercise of implementing powers." Official Journal of the European Union, Brussels, 2011.

[42] European Commission, "Comitology Procedure Reforms: Questions \& Answers," 2017. [Online]. Available: https://ec.europa.eu/commission/presscorner/detail/en/MEMO_17_273

[43] European Commission, "Report from the Commission on the working of committees during 2013. Document COM/2014/0572 final -." European Union, Brussels, 2014.

[44] European Commission, "Comitology - European Commission proposes amendments." 2017.

[45] European Commission, "Communication from the Commission to the European Parliament, the European Council and the Council - Better Regulation: Delivering better results for a stronger Union. Document COM/2016/0615 final - 14.9.2016." European Union, Brussels, 2016.

[46] European Parliament, "European Parliament resolution of 10 September 2015 on the 30th and 31st annual reports on monitoring the application of EU Law (2012-2013) (2014/2253(INI))." Official Journal of the European Union, Brussels, 2017.

[47] J. Domingues, As Ordenações Afonsinas - Três séculos de direito medieval (1211-1512). Zéfiro, 2008.

[48] Council of the European Union, "Council Regulation (EU) n. ${ }^{\circ} 216 / 2013$ of 7 March 2013 on the electronic publication of the Official Journal of the European Union." Official Journal of the European Union, Brussels, 2013.

[49] European Commission, "Proposal for a Council Regulation amending Regulation (EU) No $216 / 2013$ on the electronic publication of the Official Journal of the European Union. Document COM/2017/087 final - 2017/039 - 23.2.2017." European Union, Brussels, 2017. 
[50] European Union, "Décision des représentants des gouvernements des États membres relative à l'installation provisoire de certaines institutions et de certains services des Communautés." Official Journal of the European Communities, 1967.

[51] European Union, "Décision du 16 janvier 1969, portant installation de l'Office des publications officielles des Communautés européennes." Official Journal of the European Communities, 1969.

[52] European Union, "Decision of the European Parliament, the Council, the Commission, the Court of Justice, the Court of Auditors, the Economic and Social Committee and the Committee of the Regions of 20 July 2000 on the organization and operation of the Office for Official." Official Journal of the European Communities, 2000.

[53] European Union, "Decision of the European Parliament, the Council, the Commission, the Court of Justice of the European Union, the Court of Auditors, the European Economic and Social Committee and the Committee of the Regions of 29 June 2012 amending Decision 2009/496/EC,." Official Journal of the European Union, 2012.

[54] European Union, "Publications Office of the European Union." [Online]. Available: https://op.europa.eu/pt/home

[55] Official Journal of the European Communities, "Information regarding the entry into force of the Treaty of Nice amending the Treaty on European Union, the Treaties establishing the European Communities and certain related Acts, signed at Nice on 26 February 2001." Official Journal of the European Communities, 2003.

[56] Official Journal of the European Union, "Official Journal of the European Union, L 27, 01 February 2003." Official Journal of the European Union, 2003.

[57] Official Journal of the European Communities, "Official Journal of the European Union, L 23, 28 January 2003." Official Journal of the European Communities, 2003.

[58] European Commission, "Report from the Commission to the Council and the European Parliament Ex post evaluation report on the Civil Justice Programme (2007-2013). Document COM/2017/059 final - 13.2.2017." European Union, Brussels, 2017.

[59] European Commission, "European Commission - Public Opinion." [Online]. Available: https://ec.europa.eu/commfrontoffice/publicopinion/index.cfm/survey/getsurveydetail/instruments/fl ash/surveyky/2260.

[60] European Parliament, "European Parliament resolution of 12 March 2014 on the EU Citizenship Report 2013. EU citizens: your rights, your future (2013/2186(INI))." Official Journal of the European Union, 2017.

[61] European Commission, "Commission communication better monitoring of the application of Community law. COM/2002/0725 final - 11.12.2002." European Union, 2002.

[62] D. R. Alves and M. C. Bento, "A noção de jurisdição para efeitos de interpelação de recurso prejudicial: a questão dos tribunais arbitrais," Rev. Jurídica Portucalense, vol. 17, no. 1, pp. 89118, 2015.

[63] D. R. Alves and H. E. Claro, "Perspectiva sobre a formação judiciária na União Europeia," Rev. Julg., 2016.

[64] Court of Justice of the European Union, "Judgement of 13 July 2006, Manfredi, C-295/04, ECLI:EU:C:2006:461." Court of Justice of the European Union, 2006.

[65] European Parliament, "Directive 2014/104/EU of the European Parliament and of the Council of 26 November 2014 on certain rules governing actions for damages under national law for infringements of the competition law provisions of the Member States and of the European Union." Official Journal of the European Union, 2014.

[66] Court of Justice of the European Union, "Judgement of 20 September 2001, Courage Ltd/Bernard Crehan, C-453/99, ECLI:EU:C:2001:465.” Court of Justice of the European Union, 2001.

[67] Commission of the European Communities, "White paper on damages actions for breach of the EC antitrust rules \{SEC(2008) 404\} \{SEC(2008) 405\} \{SEC(2008) 406\} - Document COM/2008/0165 final - 2.04.2008." European Union, Brussels, 2008. 
[68] A. Silveira and S. P. Fernandes, "Justice in a time of crisis: the role of European courts as guardians of democracy," UNIO - EU Law J., pp. 11-37, Jun. 2019.

[69] European Commission, "Communication from the Commission to the Council and the European Parliament - Updating the handling of relations with the complainant in respect of the application of Union law. Document COM/2012/0154 final." European Union, 2012.

[70] European Commission, "Antitrust: Commission introduces new anonymous whistleblower tool," 2017. [Online]. Available: https://ec.europa.eu/commission/presscorner/detail/en/IP_17_591.

[71] A. Silveira, "Do âmbito de aplicação da Carta dos Direitos Fundamentais da União Europeia: recai ou não recai? - Eis a questão!," Julgar, no. 22, pp. 179-209, 2014.

[72] European Commission, "Have Your Say," 2019. [Online]. Available: https://ec.europa.eu/info/law/better-regulation/have-your-say.

[73] European Commission, "Consultations - European Commission." [Online]. Available: https://ec.europa.eu/info/consultations_pt.

[74] European Economic and Social Committee, "Opinion of the European Economic and Social Committee on the communication from the Commission to the European Parliament, the Council, the European Economic and Social Committee and the Committee of the Regions launching a consultation on a European Pill." Official Journal of the European Union, 2017. 